\title{
Degradation of pulp and paper-mill effluent by thermophilic micro-organisms using batch systems
}

\author{
Prenaven Reddy ${ }^{1}$, Visvanathan L Pillay ${ }^{2}$, Adinarayana Kunamneni' ${ }^{1}$ and Suren Singh ${ }^{1 *}$ \\ ${ }^{1}$ Department of Biotechnology, Durban Institute of Technology, PO Box 1334, Durban 4000, South Africa \\ ${ }^{2}$ Department of Chemical Engineering, Durban Institute of Technology, PO Box 1334, Durban 4000, South Africa
}

\begin{abstract}
Paper manufacturers produce large quantities of wastewater, which can have deleterious effects on the receiving waters; therefore there is a need to find a treatment process which can minimize these effects considerably. A suitable aerobic biological treatment process that can be used with great success involves the use of thermophilic micro-organisms. This technology has many advantages, which include rapid biodegradation rates, low sludge yields, and excellent process stability. Batch studies were conducted on two types of activated sludge (pulp-mill sludge and sewage sludge) at $40^{\circ} \mathrm{C}, 50^{\circ} \mathrm{C}$ and $60^{\circ} \mathrm{C}$ to determine the feasibility of thermophilic degradation of bleach pulp-mill effluent in terms of increasing aeration, biomass concentration and nutrient addition. Preliminary batch studies had confirmed the feasibility of thermophilic degradation, as COD removal achieved with the pulp-mill sludge was $55.2 \%, 37.6 \%$ and $31.4 \%$ at $40^{\circ} \mathrm{C}, 50^{\circ} \mathrm{C}$ and $60^{\circ} \mathrm{C}$ after $5 \mathrm{~d}$, respectively while the COD removal with sewage sludge was $50.2 \%, 37.3 \%$ and $27 \%$ under the same conditions. Degradation was further improved, using the same inocula in subsequent experiments and this confirmed that an acclimatization period is required, prior to degrading the bleach pulp-mill effluent. Thermophilic degradation of pulp-mill effluent occurs at temperatures of up to $60^{\circ} \mathrm{C}$; however, once final degradation is obtained, it decreases significantly as temperature increases.
\end{abstract}

Keywords: thermophilic micro-organisms, pulp and paper mill effluent, degradation, batch systems

\section{Introduction}

There has been considerable concern about the effect of chlorinated organic matter in pulp-mill effluents on the environment. Some members of this family are known to be toxic, mutagenic, persistent, and bioaccumulating, and are thought to cause numerous harmful disturbances in biological systems. The paper manufacturer generates significant quantities of wastewater, as high as $60 \mathrm{~m}^{3} / \mathrm{t}$ of paper produced. The raw wastewaters from paper and board mills can be potentially very polluting. Indeed, a recent survey within the UK industry has found that their chemical oxygen demand (COD) can be as high as 11000 $\mathrm{mg} / \ell$ Thompson et al. (2001).

The paper and board industry is actively investigating closed water systems in the production line resulting in the so-called zero discharge paper-mills. Operation of these zero-discharge mills was shown to be possible in the board industry but requires an in-line treatment system to prevent bad odours in the endproducts (Vogelaar et al., 2000). A sequenced anaerobic-aerobic treatment system was considered to be the most cost-effective option for in-line treatment of process water from a paper-mill using recycled wastepaper as a raw material. A disadvantage of their set-up is the required cooling of the process water to mesophilic conditions prior to biological treatment and subsequent heating afterwards (LaPara and Alleman, 1999).

The first investigation of thermophilic aerobic biological treatment, focusing on high-temperature board-mill wastewater was conducted in 1953. Biological oxygen demand (BOD) removal at thermophilic temperatures was slightly less than analogous mesophilic reactors after $24 \mathrm{~h}$. Although the initial degradation rates were highest at $50^{\circ} \mathrm{C}$, poor bacterial settling limited final effluent BOD quality. The addition of a coagulant

* To whom all correspondence should be addressed.

푱 +2731 3085321; fax: +2731 3085351;

e-mail: singhs@dit.ac.za

Received 28 April 2005; accepted in revised form 17 August 2005 (alum) increased BOD removal (LaPara and Alleman, 1999) by thermophilic systems to $95 \%$.

Pulp and paper industries commonly discharge a waste stream that is relatively hot $\left(50^{\circ} \mathrm{C}\right)$ compared to other industrial wastewaters. Different investigators have attempted to treat pulp and paper wastewaters at the thermophilic temperature at which they are discharged in an attempt to reduce energy costs for treatment. Rudolfs and Amberg (1953) investigated the biological treatment for white water discharged from the board mills at temperatures up to $50^{\circ} \mathrm{C}$. BOD removal in excess of $90 \%$ was possible only with the addition of chemical coagulant (alum). Gehm (1956) successfully treated kraft-mill influent for three months at temperatures from $50^{\circ} \mathrm{C}$ to $53^{\circ} \mathrm{C}$ and a $\mathrm{pH}$ of 9.5 to 9.8 . Compared with treatment at low temperatures $\left(30^{\circ} \mathrm{C}\right.$ to $38^{\circ} \mathrm{C}$ ), similar BOD removals were observed. Dissolved oxygen concentration was non-detectable, but apparently had no adverse effect on process performance. Settling characteristics were "excellent" with sustainable mixed liquor solids concentration up to $3000 \mathrm{mg} / \ell$. Carpenter et al. (1968) compared the aerobic treatment of pulp and paper wastewater at temperatures of $26^{\circ} \mathrm{C}, 37^{\circ} \mathrm{C}, 42^{\circ} \mathrm{C}, 47^{\circ} \mathrm{C}$ and $52^{\circ} \mathrm{C}$. Effluent BOD increased at higher temperatures from a maximum removal percentage of $80.5 \%\left(37^{\circ} \mathrm{C}\right)$ to a low of $37 \%\left(52^{\circ} \mathrm{C}\right)$. A low sludge volume index (SVI) was measured at thermophilic temperatures $\left(47^{\circ} \mathrm{C}\right.$ and $52^{\circ} \mathrm{C}$ ) indicative of dispersed microbial growth.

Pertulla et al. (1991) treated sulphite mill condensates containing acetate and ammonia at $65^{\circ} \mathrm{C}$ in packed-bed bioreactors, attempting to save energy by decreasing cooling requirements before treatment and reheating prior recycling the treated effluent. Extensive growth was observed, even to the point of clogging an activated carbon packing media. Overall, acetate removal was similar to that of mesophilic processes. Rintala and Lepisto (1993) treated bleached kraft-mill effluent by both anaerobic-aerobic and aerobic bench-scale processes at $55^{\circ} \mathrm{C}$. Both systems studied provided levels of COD and adsorbable organic halogen (AOX) removal similar to analogous mesophilic systems. 
Barr et al. (1996) investigated the effects of hydraulic residence time (HRT), solids residence time (SRT), and temperature on the aerobic treatment of kraft pulping effluent. Similar BOD removal was observed at $41^{\circ} \mathrm{C}$ to $50^{\circ} \mathrm{C}$ as mesophilic temperatures, and a higher COD removal was reported. Settling characteristics improved with higher temperatures. The authors attributed these unique results to the use of an external clarification system, which extended the SRT to approximately $15 \mathrm{~d}$.

The aim of this research was to determine the feasibility of thermophilic degradation of pulp-mill effluent using activated sludge as the inoculum in batch systems. This paper describes research in which the aerobic treatment of paper and pulp-mill effluent was investigated under thermophilic conditions.

\section{Materials and methods}

\section{Bleach pulp-mill effluent}

Bleach pulp-mill effluent was obtained from the SAPPI-Enstra pulp-mill (Springs, Gauteng, South Africa), from the inlet to the primary clarifier on a weekly basis, and transported to the laboratory within $2 \mathrm{~d}$ in $25 \ell$ polypropylene containers. The effluent was stored at $4{ }^{\circ} \mathrm{C}$ until required. Prior to experiments, urea and potassium di-hydrogen phosphate were added to give a COD: N: $\mathrm{P}$ ratio of 100:5:1 to simulate conditions at SAPPI-Enstra. The $\mathrm{pH}$ of the effluent was adjusted to 7.0 with either concentrated orthophosphoric acid (AR grade-Unilab) or $10 \mathrm{M}$ sodium hydroxide.

\section{Inocula}

Inoculum was obtained from the return activated sludge plant at SAPPI-Enstra, while the sewage sludge inoculum was obtained from eThekwini Northern Waste Treatment Water Works, KwaZulu-Natal, South Africa.

Previously, the inocula (pulp-mill sludge) received from SAPPI-Enstra and eThekwini Northern Waste Treatment Works were stored at $4^{\circ} \mathrm{C}$ until required. There were strong indications, however, that the inoculum was turning non-viable/anaerobic. The storage techniques for both sludge inocula of biomass were corrected and were then stored in large aerated containers, fed daily with SAPPI-Enstra effluent

On receiving the pulp-mill and sewage sludge from the respective plants, the sludges were immediately transferred to two $20 \ell$ glass fish tanks. Two fish tank air pumps (Petpro) with four ports for aeration and a recirculating pump (Rena), connected to silicone tubing were used to aerate the inoculum from the pulp-mill and sewage sludge. Viability of the sludge was maintained by removing $2 \ell$ of the contents from the fish tanks daily and adding $2 \ell$ of fresh $\mathrm{pH}$ adjusted effluent. The $\mathrm{pH}$ of the sludges was monitored daily. The viability of the sludge inocula was maintained on a continuous basis in order to use the sludges as inocula for experiments. Biomass concentrations were maintained from 2 to $4 \mathrm{~g} / \ell$. This system only served as a biomass reservoir and no scientific readings were recorded.

\section{Shake flask tests}

Two potential problems were identified here. Firstly, the initial inocula for the shake flask tests were probably too small (below $0.5 \mathrm{~g} / \ell)$. Whilst this would not affect the ultimate degradation, a lengthy retention time would be required to reach maximum degradation. This was corrected by increasing the biomass concentration in the inoculum reservoir, and subsequently ensuring (by calculation) that the inoculum concentration in the flasks were at least $2 \mathrm{~g} / \ell$ to $4 \mathrm{~g} / \ell$.

The second problem concerned the availability of oxygen in the shake flasks. It was strongly suspected that the rate of oxygen transfer in the previous shake flask trials were insufficient to maintain aerobic growth. Whilst the shake flask trials were carried out strictly according to the "standard" protocol for shake flask trials (150 r/min in a shaker incubator), the biomass concentrations in the current trials were significantly higher than those in "standard" shake flask trials. Accordingly, while agitation may be an adequate means to aerate "standard" shake flask experiments, it was most probably inadequate for the higher biomass concentrations used here.

To overcome the above, flasks were aerated, after being heated to the appropriate temperatures in water baths. Initially compressed oxygen was used for aeration, and thereafter "fish tank" aerators replaced this, which facilitated good mixing for heat transfer. Due to evaporation losses, de-ionised water was added to the flasks to maintain the liquid volume.

\section{Batch cultivation trials at thermophilic temperatures}

Experiments A and B were performed to assess the feasibility of degradation of pulp-mill effluent as described below.

\section{Pulp mill effluent degradation - Experiment $A$}

Effluent (pH 7.0) from a bleach pulp-mill plant (SAPPI - Enstra) was transferred into $2 \ell$ Erlenmeyer flasks (working volume, $1 \ell)$ and inoculated with pulp-mill sludge and sewage activated sludge $(2.5 \mathrm{~g} / \ell)$. The effluent was incubated at $40^{\circ} \mathrm{C}, 50^{\circ} \mathrm{C}$ and $60^{\circ} \mathrm{C}$ in water baths. The volumes of the effluent were also controlled daily, to overcome evaporative losses, by the addition of deionised water. COD analyses were performed daily after inoculation for a period of $5 \mathrm{~d}$.

\section{Pulp mill effluent degradation - Experiment $B$}

Flasks containing untreated bleach pulp-mill effluent ( $\mathrm{pH} 7.0)$ were inoculated with the pulp-mill sludge and sewage sludge developed from Experiment A, and this was accomplished by centrifuging the entire contents of the flasks in Experiment $\mathrm{A}$ and reconstituting the pellets (biomass) only, in effluent as Experiment B. The flasks were incubated at $40^{\circ} \mathrm{C}, 50^{\circ} \mathrm{C}$ and $60^{\circ} \mathrm{C}$. Samples were removed on a daily basis and COD analyses were performed over a $5 \mathrm{~d}$ period.

\section{Optimisation studies for enhanced degradation of pulp-mill effluent using batch experiments}

\section{Effect of biomass concentration on degradation of pulp-mill effluent}

To determine the effect of increasing biomass concentration on degradation of pulp-mill effluent, flasks were inoculated with two biomass concentrations of $2.15 \mathrm{~g} / \ell$ and $3.5 \mathrm{~g} / \ell$ from both activated sludges for the degradation of pulp-mill effluent. The $\mathrm{pH}$ of the effluent was maintained at 7.0 throughout the experiments. Flasks were incubated at $40^{\circ} \mathrm{C}, 50^{\circ} \mathrm{C}$ and $60^{\circ} \mathrm{C}$ in separate water baths. COD analyses were performed daily after inoculation over $5 \mathrm{~d}$. The optimum biomass concentration of inocula was fixed in subsequent experiments.

\section{Effect of aeration on degradation of pulp-mill effluent}

Flasks containing effluent, pulp-mill sludge and sewage sludge, were incubated at $40^{\circ} \mathrm{C}, 50^{\circ} \mathrm{C}$ and $60^{\circ} \mathrm{C}$ in water baths, respectively. Aeration was varied as follows: 


\begin{tabular}{|c|c|c|c|c|c|c|c|c|c|c|c|c|}
\hline \multicolumn{13}{|c|}{$\begin{array}{r}\text { TABLE } 1 \\
\text { COD and degradation profiles of batch exp }\end{array}$} \\
\hline \multirow{3}{*}{$\begin{array}{c}\text { Time } \\
\text { (days) }\end{array}$} & \multicolumn{6}{|c|}{ Pulp mill effluent inoculated with pulp mill sludge } & \multicolumn{6}{|c|}{ Pulp mill effluent inoculated with sewage sludge } \\
\hline & \multicolumn{2}{|c|}{$40^{\circ} \mathrm{C}$} & \multicolumn{2}{|c|}{$50^{\circ} \mathrm{C}$} & \multicolumn{2}{|c|}{$60^{\circ} \mathrm{C}$} & \multicolumn{2}{|c|}{$40^{\circ} \mathrm{C}$} & \multicolumn{2}{|c|}{$50^{\circ} \mathrm{C}$} & \multicolumn{2}{|c|}{$60^{\circ} \mathrm{C}$} \\
\hline & $\begin{array}{l}\text { COD } \\
(\mathrm{mg} / \mathrm{l})\end{array}$ & $\begin{array}{l}\text { \% degra- } \\
\text { dation }\end{array}$ & $\begin{array}{l}\text { COD } \\
(\mathrm{mg} / \ell)\end{array}$ & $\begin{array}{c}\text { \% degra- } \\
\text { dation }\end{array}$ & $\begin{array}{c}\text { COD } \\
(\mathrm{mg} / \mathrm{l})\end{array}$ & $\begin{array}{l}\text { \% degra- } \\
\text { dation }\end{array}$ & $\begin{array}{l}\text { COD } \\
(\mathrm{mg} / \mathrm{l})\end{array}$ & $\begin{array}{c}\text { \% degra- } \\
\text { dation }\end{array}$ & $\begin{array}{l}\text { COD } \\
(\mathrm{mg} / \ell)\end{array}$ & $\begin{array}{c}\text { \% degra- } \\
\text { dation }\end{array}$ & $\begin{array}{l}\text { COD } \\
(\mathrm{mg} / \ell)\end{array}$ & $\begin{array}{l}\text { \% degra- } \\
\text { dation }\end{array}$ \\
\hline 0 & 938 & 0 & 916 & 0 & 948 & 0 & 940 & 0 & 925 & 0 & 945 & 0 \\
\hline 1 & 708 & 24.5 & 760 & 17.03 & 890 & 6.12 & 738 & 21.5 & 782 & 15.5 & 913 & 3.4 \\
\hline 2 & 496 & 47.1 & 648 & 29.3 & 820 & 13.5 & 525 & 44.2 & 659 & 28.8 & 880 & 6.9 \\
\hline 3 & 464 & 50.5 & 592 & 35.4 & 760 & 19.8 & 490 & 47.9 & 620 & 32.9 & 810 & 14.3 \\
\hline 4 & 448 & 52.2 & 592 & 35.4 & 710 & 25.11 & 479 & 49.04 & 600 & 35.14 & 770 & 18.5 \\
\hline 5 & 420 & 55.2 & 572 & 37.6 & 650 & 31.4 & 468 & 50.2 & 580 & 37.3 & 690 & 26.98 \\
\hline
\end{tabular}

- Single-pump aeration (referred to as normal aeration - NA),

- Two-pump aeration (referred to as double aeration - DA).

The biomass concentrations of both sludges were maintained at $3.5 \mathrm{~g} / \ell$. Samples were removed daily over a $5 \mathrm{~d}$ period and COD values were determined.

\section{Effect of nutrient addition on degradation of pulp-mill effluent}

Prior to biological treatment of the effluent at the SAPPI-Enstra plant, nutrients containing nitrogen (Urea) and phosphate (phosphoric acid) are added to give a COD:N:P ratio of 100:5:1. This was done so that the nutrients to micro-organisms ratio created an environment favourable to the floc forming organisms versus filamentous organisms, which in turn provided good settling characteristics for the sludge (Jenkins et al., 1993).

Flasks containing both sludge types were incubated at $40^{\circ} \mathrm{C}$, $50^{\circ} \mathrm{C}$ and $60^{\circ} \mathrm{C}$. Nutrient additions were varied as follows:

- COD:N:P at a ratio of 100:5:1, referred to as standard nutrients (SN) which is applied at SAPPI-Enstra

- COD: N: $P$ at a ratio of 100:10:2, referred to as double nutrients (DN). The biomass concentrations of both sludge inocula were maintained at $3.5 \mathrm{~g} / \ell$. Samples were removed daily over a $5 \mathrm{~d}$ period and COD values were determined.

\section{Analytical methods}

Mixed liquor suspended solids (MLSS) and COD analyses MLSS and COD were determined according to Standard Methods (1995).

\section{Results and discussion}

\section{Pulp mill effluent degradation - Experiment $A$ vs. Experiment $B$}

Experiment A was conducted to determine whether aerobic thermophilic treatment of bleach pulp-mill effluent was feasible. The flasks inoculated with pulp-mill sludge at $40^{\circ} \mathrm{C}$ demonstrated a decrease in COD after $24 \mathrm{~h}(708 \mathrm{mg} / \mathrm{\ell})$, and a final COD value of $420 \mathrm{mg} /$ lwas obtained after $5 \mathrm{~d}$. (Table 1). Flasks inoculated with pulp-mill sludge at $50^{\circ} \mathrm{C}$ and $60^{\circ} \mathrm{C}$ also showed decreased COD values, at a gradual rate finally reduced to $572 \mathrm{mg} / \mathrm{l}$ at $50^{\circ} \mathrm{C}$ and $650 \mathrm{mg} / \ell$ at $60^{\circ} \mathrm{C}$ by day five. This confirmed that degradation does occur at thermophilic temperatures, however not as efficiently as at $40^{\circ} \mathrm{C}$. The SAPPI activated sludge plant operates between $25^{\circ} \mathrm{C}$ and $37^{\circ} \mathrm{C}$ and, therefore, degradation is more pronounced at $40^{\circ} \mathrm{C}$, as compared to $50^{\circ} \mathrm{C}$ and $60^{\circ} \mathrm{C}$.

The overall COD removal for pulp-mill sludge varied from 24.5 to $55.2 \%, 17.0$ to $37.6 \%$, and 6.1 to $31.4 \%$ for the batch sys- tems operating at $40^{\circ} \mathrm{C}, 50^{\circ} \mathrm{C}$ and $60^{\circ} \mathrm{C}$, respectively. The COD removal of the batch system inoculated with pulp-mill sludge at $50^{\circ} \mathrm{C}$ and $60^{\circ} \mathrm{C}$ was significantly lower than the batch system at $40^{\circ} \mathrm{C}$. These results are in agreement with previous findings of Tripathi and Allen (2000) for bleach pulp-mill effluent studied at $45^{\circ} \mathrm{C}, 55^{\circ} \mathrm{C}$ and $60^{\circ} \mathrm{C}$ in a sequencing batch reactor (SBR). The results showed that $40^{\circ} \mathrm{C}$ is the ideal temperature for degradation of bleach pulp-mill effluent. Tripathi and Allen (2000) achieved COD removal at the following temperatures: $45^{\circ} \mathrm{C}$ $(63 \pm 8 \%), 55^{\circ} \mathrm{C}(52 \pm 8 \%)$ and $60^{\circ} \mathrm{C}(50 \pm 6 \%)$, while operating an SBR over 40 weeks.

Inoculation with sewage sludge was able to reduce the CODs of the effluent to $468 \mathrm{mg} / \ell$ at $40^{\circ} \mathrm{C}, 580 \mathrm{mg} / \ell$ at $50^{\circ} \mathrm{C}$ and 690 $\mathrm{mg} / \ell$ at $60^{\circ} \mathrm{C}$ by day five (Table 1 ). The overall COD removal for the batch system inoculated with sewage sludge varied from: 21.5 to $50.2 \%, 15.5 \%$ to $37.3 \%$ and $3.4 \%$ to $26.9 \%$, for $40^{\circ} \mathrm{C}, 50^{\circ} \mathrm{C}$ and $60^{\circ} \mathrm{C}$, respectively. The same trends were observed with both sludge types, i.e., higher temperature results in decreased COD removal. Pulp-mill sludge demonstrated higher COD removal than sewage sludge at $40^{\circ} \mathrm{C}, 50^{\circ} \mathrm{C}$ and $60^{\circ} \mathrm{C}$ (Table 1). Due to acclimatisation factors it was expected that sewage sludge being sourced from a domestic wastewater treatment facility would not degrade the effluent as efficiently as pulp-mill sludge. A subsequent concern arose regarding the viability of pulp-mill sludge, in this study, as the sludge was normally in transit for $48 \mathrm{~h}$ prior to experimentation. Studies conducted by Tripathi and Allen (2000) indicated that organisms present in activated sludge required an acclimatisation period prior to degrading the bleach pulp-mill effluent efficiently at thermophilic temperatures.

The two sludge types (pulp-mill sludge and sewage sludge) used in Experiment A served as the inocula for Experiment B. The pulp-mill sludge showed better degradation of effluent. After $5 \mathrm{~d}$ the CODs were reduced to $374 \mathrm{mg} / \ell, 465 \mathrm{mg} / \ell$ and $578 \mathrm{mg} / \ell$ at $40^{\circ} \mathrm{C}, 50^{\circ} \mathrm{C}$ and $60^{\circ} \mathrm{C}$, respectively, while after $5 \mathrm{~d}$ sewage sludge reduced the CODs to $445 \mathrm{mg} / \ell, 539 \mathrm{mg} / \ell$ and $625 \mathrm{mg} / \ell$ at $40^{\circ} \mathrm{C}$, $50^{\circ} \mathrm{C}$ and $60^{\circ} \mathrm{C}$, respectively (Table 2). The overall COD removal for pulp-mill sludge was 21.1 to $59.8 \%, 11.1$ to $48.4 \%$ and 6.5 to $37.2 \%$ at $40^{\circ} \mathrm{C}, 50^{\circ} \mathrm{C}$ and $60^{\circ} \mathrm{C}$, respectively, while the overall COD removal for sewage sludge was 17.6 to $52.4 \%, 8.2$ to $41.1 \%$ and 2.7 to $32.4 \%$ at the same temperatures. In comparison to the results of Experiment A with pulp-mill sludge, Experiment B demonstrated an increase in $\mathrm{COD}$ removal $\left( \pm 4.6 \%\right.$ at $40^{\circ} \mathrm{C}, \pm 10.8 \%$ at $50^{\circ} \mathrm{C}$ and $\pm 5.8 \%$ at $60^{\circ} \mathrm{C}$ ). The sewage sludge in Experiment $\mathrm{B}$ compared to the sewage sludge in Experiment $\mathrm{A}$ also demonstrated an increase in COD reduction at all of the temperatures $\left(2.2 \%\right.$ at $40^{\circ} \mathrm{C}, 3.8 \%$ at $50^{\circ} \mathrm{C}$ and $5.4 \%$ at $60^{\circ} \mathrm{C}$ ). The increase in degradation at all three temperatures for both sludge types in Experiment B compared to Experiment A confirms that better or improved degradation is attributed to an acclimatisation period. Pulp-mill sludge was still the better inoculum of the two demonstrating an increase of COD 


\begin{tabular}{|c|c|c|c|c|c|c|c|c|c|c|c|c|}
\hline \multicolumn{13}{|c|}{$\begin{array}{c}\text { TABLE } 2 \\
\text { COD and degradation profiles of batch experiment B using pulp mill effluent inoculated with pulp mill } \\
\text { sludge and sewage sludge at thermophilic temperatures }\end{array}$} \\
\hline \multirow{3}{*}{$\begin{array}{c}\text { Time } \\
\text { (days) }\end{array}$} & \multicolumn{6}{|c|}{ Pulp mill effluent inoculated with pulp mill sludge } & \multicolumn{6}{|c|}{ Pulp mill effluent inoculated with sewage sludge } \\
\hline & \multicolumn{2}{|c|}{$40^{\circ} \mathrm{C}$} & \multicolumn{2}{|c|}{$50^{\circ} \mathrm{C}$} & \multicolumn{2}{|c|}{$60^{\circ} \mathrm{C}$} & \multicolumn{2}{|c|}{$40^{\circ} \mathrm{C}$} & \multicolumn{2}{|c|}{$50^{\circ} \mathrm{C}$} & \multicolumn{2}{|c|}{$60^{\circ} \mathrm{C}$} \\
\hline & \begin{tabular}{|c|} 
COD \\
$(\mathrm{mg} / \mathrm{l})$
\end{tabular} & \begin{tabular}{|c|}
$\%$ deg- \\
radation
\end{tabular} & \begin{tabular}{|c|} 
COD \\
$(\mathrm{mg} / \mathrm{l})$
\end{tabular} & \begin{tabular}{|c|}
$\%$ degra- \\
dation
\end{tabular} & \begin{tabular}{|c|} 
COD \\
$(\mathrm{mg} / \mathrm{l})$
\end{tabular} & \begin{tabular}{|c|}
$\%$ degra- \\
dation
\end{tabular} & $\begin{array}{c}\text { COD } \\
(\mathrm{mg} / \mathrm{l})\end{array}$ & $\begin{array}{c}\% \text { degra- } \\
\text { dation }\end{array}$ & \begin{tabular}{|c|} 
COD \\
$(\mathrm{mg} / \mathrm{l})$
\end{tabular} & \begin{tabular}{|c|}
$\%$ degra- \\
dation
\end{tabular} & \begin{tabular}{|c|} 
COD \\
$(\mathrm{mg} / \mathrm{l})$
\end{tabular} & $\begin{array}{c}\begin{array}{c}\text { \% degra- } \\
\text { dation }\end{array} \\
\end{array}$ \\
\hline 0 & 930.4 & 0 & 902.4 & 0 & 920 & 0 & 935 & 0 & 915 & 0 & 925 & 0 \\
\hline 1 & 734 & 21.1 & 802 & 11.1 & 860 & 6.5 & 770 & 17.6 & 840 & 8.2 & 900 & 2.7 \\
\hline 2 & 634 & 32 & 748 & 17.1 & 780 & 15.2 & 674 & 27.9 & 779 & 14.9 & 820 & 11.4 \\
\hline 3 & 528 & 43.3 & 598 & 33.7 & 695 & 24.5 & 569 & 39.1 & 639 & 30.2 & 715 & 22.7 \\
\hline 4 & 410 & 55.9 & 489 & 45.8 & 590 & 35.9 & 460 & 49.9 & 555 & 39.3 & 660 & 28.6 \\
\hline 5 & 374 & 59.8 & 465 & 48.4 & 578 & 37.2 & 445 & 52.4 & 539 & 41.1 & 625 & 32.4 \\
\hline
\end{tabular}

\begin{tabular}{|c|c|c|c|c|c|c|c|c|c|c|c|c|}
\hline \multicolumn{13}{|c|}{$\begin{array}{l}\text { TABLE } 3 \\
\text { COD and degradation profiles of batch experiment using pulp mill effluent inoculated with pulp mill } \\
\text { sludge at } 2.15 \mathrm{~g} / \ell \text { and } 3.5 \mathrm{~g} / \ell \text { at thermophilic temperatures }\end{array}$} \\
\hline \multirow{4}{*}{$\begin{array}{l}\text { Time } \\
\text { (d) }\end{array}$} & \multicolumn{12}{|c|}{ Pulp mill effluent + pulp mill sludge } \\
\hline & \multicolumn{6}{|c|}{ Biomass $2.15 \mathrm{~g} / \mathrm{l}$} & \multicolumn{6}{|c|}{ Biomass $3.5 \mathrm{~g} / \mathrm{\ell}$} \\
\hline & \multicolumn{2}{|c|}{$40^{\circ} \mathrm{C}$} & \multicolumn{2}{|c|}{$50^{\circ} \mathrm{C}$} & \multicolumn{2}{|c|}{$60^{\circ} \mathrm{C}$} & \multicolumn{2}{|c|}{$40^{\circ} \mathrm{C}$} & \multicolumn{2}{|c|}{$50^{\circ} \mathrm{C}$} & \multicolumn{2}{|c|}{$60^{\circ} \mathrm{C}$} \\
\hline & $\begin{array}{c}\text { COD } \\
(\mathrm{m} \mathrm{g} / \mathrm{l})\end{array}$ & $\begin{array}{c}\text { \% degra- } \\
\text { dation }\end{array}$ & \begin{tabular}{|c|} 
COD \\
$(\mathrm{m} / \mathrm{g} / \mathrm{\ell})$ \\
\end{tabular} & $\begin{array}{c}\text { \% degra- } \\
\text { dation }\end{array}$ & $\begin{array}{l}\text { COD } \\
\text { (g/e) }\end{array}$ & \begin{tabular}{|c|}
$\begin{array}{c}\% \text { degra- } \\
\text { dation }\end{array}$ \\
\end{tabular} & $\begin{array}{l}\text { COD } \\
(\mathrm{g} / \ell)\end{array}$ & $\begin{array}{c}\% \text { degra- } \\
\text { dation }\end{array}$ & $\begin{array}{l}\text { COD } \\
\text { (g/e) }\end{array}$ & \begin{tabular}{|c|}
$\begin{array}{c}\% \text { degra- } \\
\text { dation }\end{array}$ \\
\end{tabular} & $\begin{array}{l}\text { COD } \\
(g / \ell)\end{array}$ & $\begin{array}{c}\% \text { degra- } \\
\text { dation }\end{array}$ \\
\hline 0 & 764 & 0 & 772 & 0 & 780 & 0 & 868 & 0 & 862 & 0 & 875 & 0 \\
\hline 1 & 540 & 29.32 & 590 & 23.58 & 626 & 19.74 & 498 & 42.6 & 586 & 32.02 & 660 & 24.57 \\
\hline 2 & 500 & 34.55 & 556 & 27.98 & 594 & 23.85 & 426 & 50.9 & 570 & 33.87 & 630 & 28 \\
\hline 3 & 460 & 39.7 & 521 & 32.51 & 568 & 27.18 & 416 & 52.07 & 550 & 36.19 & 590 & 32.57 \\
\hline 4 & 428 & 43.9 & 495 & 35.88 & 548 & 29.74 & 404 & 53.5 & 520 & 39.68 & 570 & 34.86 \\
\hline 5 & 420 & 45 & 480 & 37.82 & 535 & 31.41 & 397 & 54.26 & 510 & 40.83 & 565 & 35.43 \\
\hline
\end{tabular}

\begin{tabular}{|c|c|c|c|c|c|c|c|c|c|c|c|c|}
\hline \multicolumn{13}{|c|}{$\begin{array}{l}\text { TABLE } 4 \\
\begin{array}{l}\text { COD and degradation profiles of batch experiment using pulp mill effluent inoculated with sewage sludge } \\
\text { at } 2.15 \mathrm{~g} / \ell \text { and } 3.5 \mathrm{~g} / \ell \text { at thermophilic temperatures }\end{array}\end{array}$} \\
\hline \multirow{4}{*}{$\begin{array}{c}\text { Time } \\
\text { (days) }\end{array}$} & \multicolumn{12}{|c|}{ Pulp mill effluent + sewage sludge } \\
\hline & \multicolumn{6}{|c|}{$2.15 \mathrm{~g} / \ell$} & \multicolumn{6}{|c|}{$3.5 \mathrm{~g} / \mathrm{l}$} \\
\hline & \multicolumn{2}{|c|}{$40^{\circ} \mathrm{C}$} & \multicolumn{2}{|c|}{$50^{\circ} \mathrm{C}$} & \multicolumn{2}{|c|}{$60^{\circ} \mathrm{C}$} & \multicolumn{2}{|c|}{$40^{\circ} \mathrm{C}$} & \multicolumn{2}{|c|}{$50^{\circ} \mathrm{C}$} & \multicolumn{2}{|c|}{$60^{\circ} \mathrm{C}$} \\
\hline & $\begin{array}{l}\text { COD } \\
(\mathrm{mg} / \mathrm{l})\end{array}$ & $\begin{array}{c}\text { \% degra- } \\
\text { dation }\end{array}$ & $\begin{array}{c}\text { COD } \\
(\mathrm{mg} / \mathrm{l})\end{array}$ & $\begin{array}{c}\text { \% degra- } \\
\text { dation }\end{array}$ & $\begin{array}{l}\text { COD } \\
(\mathrm{mg} / \mathrm{l})\end{array}$ & $\begin{array}{c}\text { \% degra- } \\
\text { dation }\end{array}$ & $\begin{array}{l}\text { COD } \\
(\mathrm{mg} / \mathrm{l})\end{array}$ & $\begin{array}{c}\text { \% degra- } \\
\text { dation }\end{array}$ & $\begin{array}{c}\text { COD } \\
(\mathrm{mg} / \mathrm{l})\end{array}$ & $\begin{array}{c}\text { \% degra- } \\
\text { dation }\end{array}$ & \begin{tabular}{|c|} 
COD \\
$(\mathrm{mg} / \mathrm{l})$
\end{tabular} & $\begin{array}{c}\text { \% degra- } \\
\text { dation }\end{array}$ \\
\hline 0 & 788 & 0 & 776 & 0 & 788 & 0 & 880 & 0 & 884 & 0 & 891 & 0 \\
\hline 1 & 560 & 28.93 & 620 & 20.1 & 657 & 16.6 & 564 & 35.9 & 650 & 26.47 & 730 & 18.06 \\
\hline 2 & 535 & 32.11 & 586 & 24.48 & 621 & 21.19 & 523 & 40.57 & 610 & 30.99 & 680 & 23.68 \\
\hline 3 & 520 & 34.01 & 550 & 29.12 & 590 & 25.13 & 490 & 44.3 & 580 & 34.38 & 658 & 26.15 \\
\hline 4 & 500 & 36.55 & 525 & 32.3 & 575 & 27.03 & 478 & 45.68 & 567 & 35.86 & 623 & 30.07 \\
\hline 5 & 495 & 37.18 & 515 & 33.63 & 569 & 27.79 & 470 & 46.59 & 559 & 36.76 & 615 & 30.98 \\
\hline
\end{tabular}

removal at each of the temperatures investigated $\left(7.4 \%\right.$ at $40^{\circ} \mathrm{C}$, $7.3 \%$ at $50^{\circ} \mathrm{C}$ and $4.8 \%$ at $60^{\circ} \mathrm{C}$ ).

\section{Optimisation studies for enhanced degradation of pulp-mill effluent using batch experiments}

\section{Effect of biomass concentration on degradation of pulp-mill effluent}

Experiments were conducted to determine whether the effluent degradation was enhanced with increasing biomass concentrations of both sludge inocula. The flasks inoculated with pulpmill sludge $(2.15 \mathrm{~g} / \ell)$ at $40^{\circ} \mathrm{C}, 50^{\circ} \mathrm{C}$ and $60^{\circ} \mathrm{C}$ were able to reduce the COD's to $420 \mathrm{mg} / \ell, 552 \mathrm{mg} / \ell$ and $580 \mathrm{mg} / \ell$, respectively (Table 3). The flasks inoculated with pulp-mill sludge $(3.5 \mathrm{~g} / \ell)$ after five days reduced COD's to $397 \mathrm{mg} / \ell, 510 \mathrm{mg} / \ell$ and 565 $\mathrm{mg} / \ell$ (Table 3.). The overall COD removal for pulp-mill sludge with a biomass concentration of $2.15 \mathrm{~g} / \ell$ observed was 29.3 to
$45.0 \%$ at $40^{\circ} \mathrm{C}, 23.6$ to $37.8 \%$ at $50^{\circ} \mathrm{C}$ and 19.7 to $31.4 \%$ at $60^{\circ} \mathrm{C}$, and with $3.5 \mathrm{~g} / \ell$, COD removal was 42.6 to $54.3 \%$ at $40^{\circ} \mathrm{C}, 32.0$ to $40.8 \%$ at $50^{\circ} \mathrm{C}$ and 24.6 to $35.4 \%$ at $60^{\circ} \mathrm{C}$.

The overall COD removal for sewage sludge with a biomass concentration of $2.15 \mathrm{~g} / \ell$ demonstrated: 28.9 to $37.2 \%$ at $40^{\circ} \mathrm{C}$, 20.1 to $33.6 \%$ at $50^{\circ} \mathrm{C}$ and 16.6 to $27.8 \%$ at $60^{\circ} \mathrm{C}$, with $3.5 \mathrm{~g} / \ell$ demonstrated: 35.9 to $46.6 \%$ at $40^{\circ} \mathrm{C}, 26.5$ to $36.8 \% 50^{\circ} \mathrm{C}$ and 18.1 to $31.0 \% 60^{\circ} \mathrm{C}$ (Table 4 ).

Pulp-mill sludge showed better effluent degradability as compared to sewage sludge at each of the biomass concentrations investigated (at a biomass of $2.15 \mathrm{~g} / \ell$ pulp-mill sludge degradation increased by $7.8 \%$ at $40^{\circ} \mathrm{C}, 4.2 \%$ at $50^{\circ} \mathrm{C}$ and $3.6 \%$ at $60^{\circ} \mathrm{C}$, while at a biomass concentration of $3.5 \mathrm{~g} / \ell$ pulp-mill sludge degradation increased by $7.7 \%$ at $40^{\circ} \mathrm{C}, 4.1 \%$ at $50^{\circ} \mathrm{C}$ and $4.5 \%$ at $60^{\circ} \mathrm{C}$, respectively). It can be concluded that biomass concentration is a critical parameter for effluent degradation. Improved degradation could be obtained, if the biomass were subjected to a longer acclimatiza- 


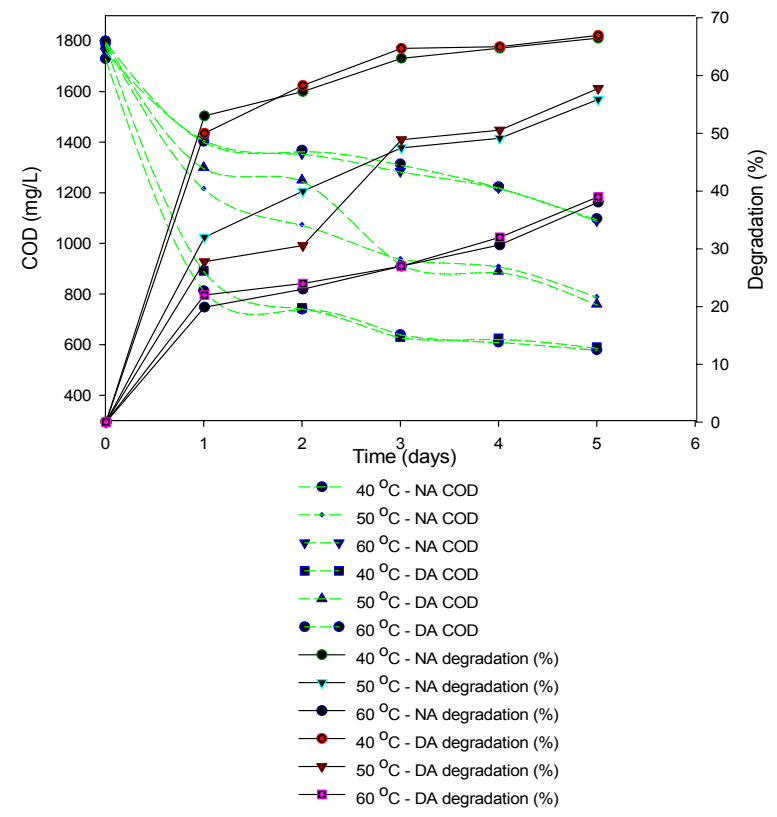

Figure 1

Effect of aeration on $C O D$ and degradation profiles of pulp-mill effluent using pulp-mill sludge as inocula at thermophilic temperatures

tion period. The best effluent degradation was observed at $40^{\circ} \mathrm{C}$ as compared to $50^{\circ} \mathrm{C}$ and $60^{\circ} \mathrm{C}$ with pulp-mill and sewage sludge.

Activated sludge plants at UK paper-mills typically operate at mean organic loading rates ranging from 0.07 to $0.21 \mathrm{~kg} \mathrm{BOD} / \mathrm{kg}$ mixed liquor suspended solids (MLSS). One critical operational aspect of an activated sludge plant is maintaining a good settling sludge. Poor settlement (bulking) has caused operational problems since the 1920s and activated sludge plants treating papermill wastewaters are prone to this. Bulking creates problems in ensuring that the correct amount of sludge is recycled back to the aeration tank to maintain the MLSS at a sufficient concentration to guarantee efficient treatment (Thompson et al., 2001).

\section{Effect of aeration on degradation of pulp-mill effluent}

The COD removed with pulp-mill sludge using normal aeration from 1 to $5 \mathrm{~d}$, was 53.0 to $66.5 \%$ at $40^{\circ} \mathrm{C}, 32.0$ to $55.9 \%$ at $50^{\circ} \mathrm{C}$ and 19.9 to $38.1 \%$ at $60^{\circ} \mathrm{C}$ while double aeration showed 50.0 to $67.0 \%$ at $40^{\circ} \mathrm{C}, 27.8$ to $57.8 \%$ at $50^{\circ} \mathrm{C}$ and 22.0 to $39.0 \%$ at $60^{\circ} \mathrm{C}$ (Fig. 1). In terms of COD removed, doubling the aeration had a minimal increase in COD removal when compared with normal aeration. This implies that the system was not a retardation factor in terms of COD removal. The same trend was true for sewage sludge, having COD removal with normal aeration observed at: 37.4 to $50.5 \%$ at $40^{\circ} \mathrm{C}, 25.8$ to $38.6 \%$ at $50^{\circ} \mathrm{C}$ and 20.44 to $31.5 \%$ at $60{ }^{\circ} \mathrm{C}$, while doubling the aeration showed: 39.0 to $51.9 \%$ at $40{ }^{\circ} \mathrm{C}$, 26 to $41.8 \%$ at $50^{\circ} \mathrm{C}$ and 21.7 to $33.3 \%$ at $60^{\circ} \mathrm{C}$ (Fig. 2). When comparing both sludge types, it is evident that pulp-mill sludge is most suitable for the bleach pulp-mill effluent degradation.

It can be concluded that increasing the aeration rate has a negligible effect on the final COD value. Rozich and Colvin (1997) have recommended utilizing aggressive aeration equipment and greater tank depth to accommodate the potential enormous oxygen requirements of thermophilic treatment processes. The simultaneous requirements for rapid and high efficiency oxygen transfer make the selection of aeration equipment one of the most critical process design choices. However, the results obtained on the batch studies are contradictory and this could be due to conducting these experiments in such a small scale.

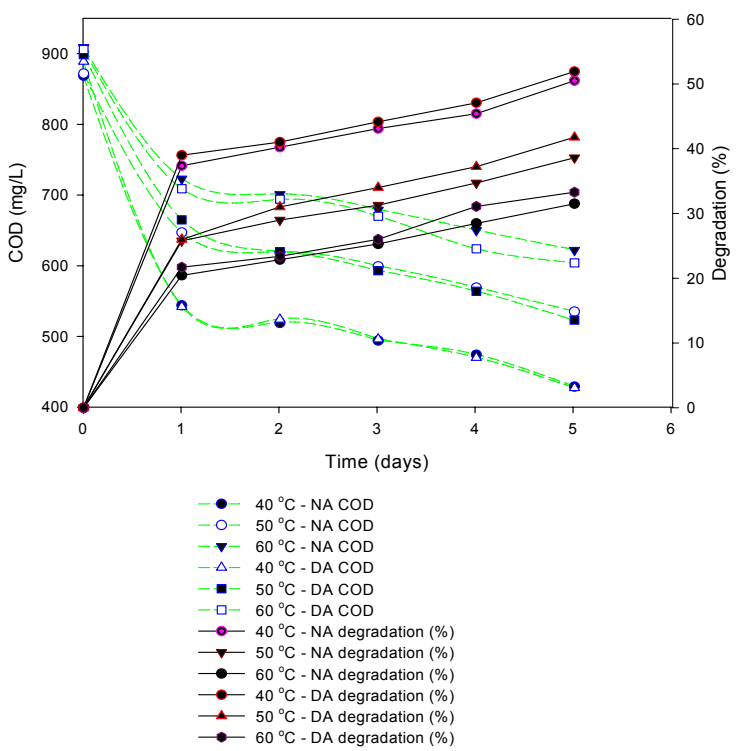

Figure 2

Effect of aeration on COD and degradation profiles of pulp-mill effluent using sewage sludge as inocula at thermophilic temperatures

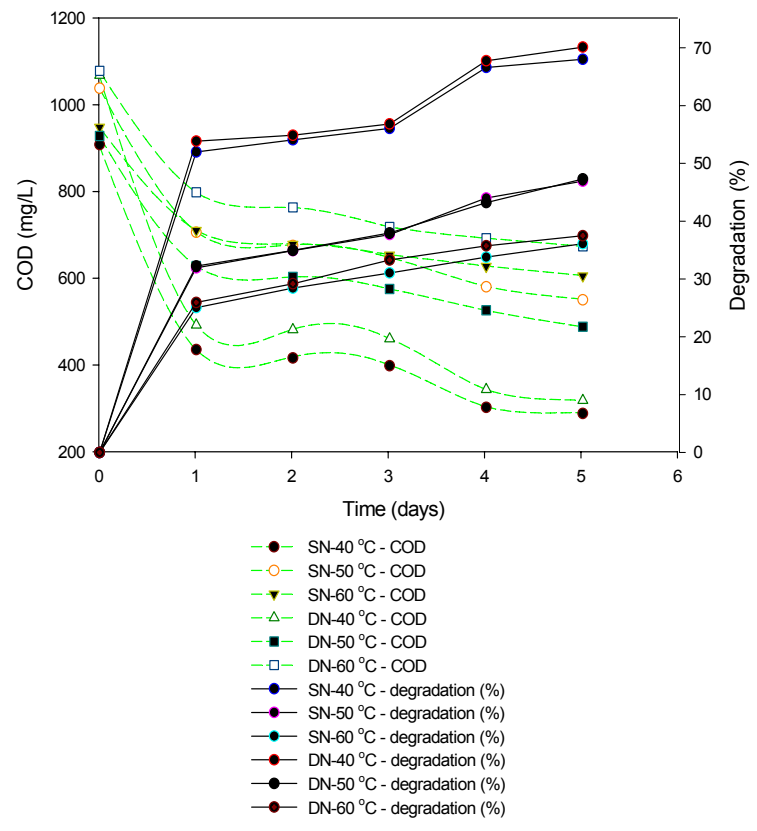

Figure 3

Effect of nutrient supplementation on $C O D$ and degradation profiles of pulp-mill effluent using pulp-mill sludge at thermophilic temperatures

\section{Effect of additional nutrients on degradation of pulp-mill effluent}

The permeate CODs obtained with double nutrient addition are slightly greater than that obtained with the normal nutrient addition. This indicates that the system was not being limited by nutrients. The CODs obtained using sewage sludge from eThekwini Northern Waste Water Treatment Works are slightly lower than that obtained with Enstra's pulp-mill sludge, possibly indicating that the inoculum used could have an effect on the degradation. At $40^{\circ} \mathrm{C}, 50^{\circ} \mathrm{C}$ and $60^{\circ} \mathrm{C}$, the degradation obtained with sewage sludge was somewhat lower than that obtained with the pulp-mill sludge.

The experiments were conducted to determine whether the additional nutrient supplementation further enhanced effluent 


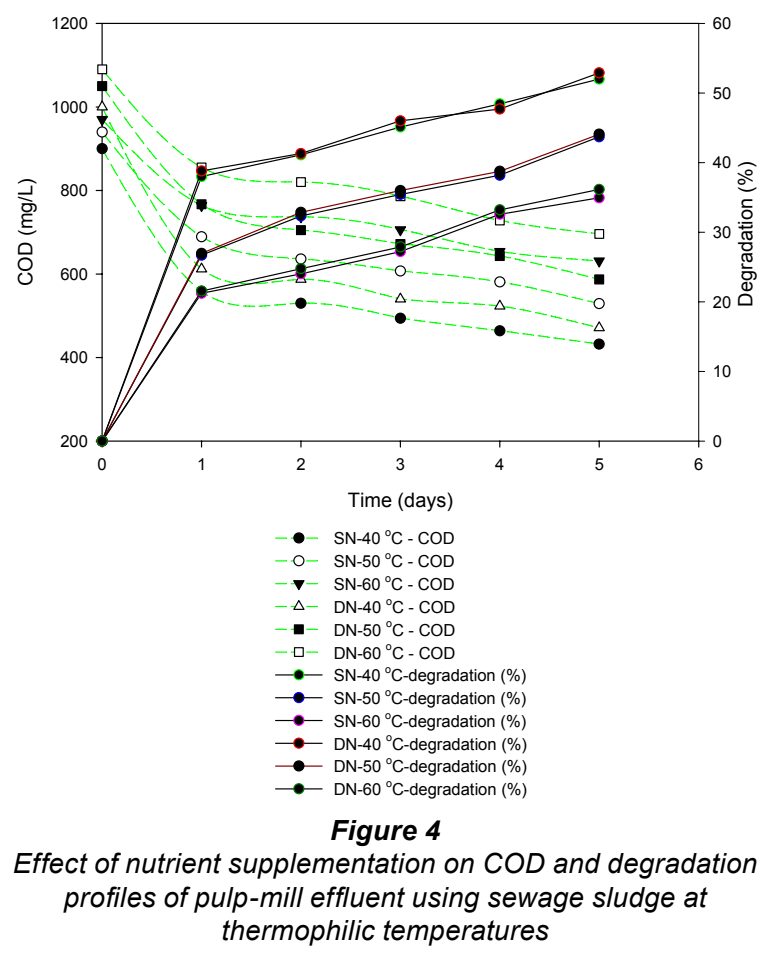

degradation. The overall COD removal for standard nutrients using pulp-mill sludge and sewage sludge obtained was: 52.0 to $68.0 \%$ and 38.0 to $52.0 \%$ at $40^{\circ} \mathrm{C} ; 31.9$ to $46.9 \%$ and 26.7 to $43.7 \%$ at $50^{\circ} \mathrm{C}, 25.1$ to $36.0 \%$ and 21.2 to $35.1 \%$ at $60^{\circ} \mathrm{C}$, respectively (Figs. 3 and 4). With additional nutrient supplementation (i.e. doubling the nutrients) with pulp-mill sludge and sewage sludge as inocula, the percentage COD removal observed was 53.8 to $70.1 \%$ and 38.8 to $52.9 \%$ at $40^{\circ} \mathrm{C}, 32.3$ to $47.3 \%$ and 27.0 to $44.1 \%$ at $50^{\circ} \mathrm{C}, 25.9$ to $37.5 \%$ and 21.6 to $36.2 \%$ at $60^{\circ} \mathrm{C}$. Additional nutrient supplementation had a slight increase in COD removed as compared to standard nutrients for both sludge types. Although the nutrient supplementation varied, the batch systems at $40^{\circ} \mathrm{C}$ still performed better as compared to $50^{\circ} \mathrm{C}$ and $60^{\circ} \mathrm{C}$. Further experiments used standard nutrients as it did not limit the batch systems. Comparing both sludges in terms of COD removal, pulp-mill sludge yet again proved to be the ideal inoculum for the treatment of bleach pulp-mill effluent.

The unique nutritional requirements of thermophilic organisms, are likely responsible for the varying success of previous researchers treating different wastes at different temperatures. The researchers reporting good results generally treated complex wastes likely to contain sufficient micronutrients or provided supplemental nutrients. For research purposes, the addition of complex nutrients such as peptone or yeast extract is usually sufficient to enable biodegradation of most readily degradable compounds. Further work is necessary to identify specific nutrient supplements suitable for full-scale operation (LaPara and Alleman, 1999).

\section{Conclusion}

The batch tests provided insight into the feasibility of thermophilic degradation of bleach pulp-mill effluent. The pulp-mill and sewage sludge treatment of the effluent significantly reduced the COD in the batch systems. A higher biomass concentration enhanced degradation in this study; however, this cannot be confirmed, as viability tests were not carried out on the sludges.
Increasing aeration and nutrient supplementation did not significantly enhance degradation. Probably scaling-up of these batch systems would prove otherwise.

Maximum degradation occurred at $40^{\circ} \mathrm{C}$ for both sludge types. The higher temperatures did not have a profound effect on COD removal. The maximum permissible or best-tested temperature for thermophilic degradation of bleach pulp-mill effluent to reduce COD efficiently was $40^{\circ} \mathrm{C}$. Pulp-mill sludge degraded the effluent much better when compared to sewage sludge. Batch systems demonstrated that an acclimatisation process is required for efficient degradation as well as that the system should be shifted to a fed-batch system to achieve better COD removal.

Thermophilic degradation of pulp and paper-mill effluent does occur at temperatures of up to $60^{\circ} \mathrm{C}$. However, the final degradation obtained decreases significantly as temperature increases: $-40^{\circ} \mathrm{C}(65 \%$ to $70 \%), 50^{\circ} \mathrm{C}(40 \%)$ and $60^{\circ} \mathrm{C}(20 \%)$. The potential exists for the application of an aerobic thermophilic treatment process for the pulp and paper industry.

\section{Acknowledgements}

The authors would like to thank the National Research Foundation (NRF) for their financial support during this study and $\mathrm{Mr} V$ Dilsook of SAPPI-Enstra for assistance in obtaining effluent and sludge samples.

\section{References}

BARR TA, TAYLOR JM, and DUFF SJB (1996) Effect of HRT, SRT and temperature on the performance of activated sludge reactors treating bleached kraft-mill effluent. Water Res. 30 (4) 799-810.

CARPENTER WL, VAMVAKIAS JG, and GELLMAN I (1968) Temperature relationships in aerobic treatment and disposal of pulp and paper wastes. JWPCF 40 (5) 733-739.

GEHM HW (1956) Activated sludge at high temperatures and high $\mathrm{pH}$ values. In: McCabe J and Eckenfelder WW (eds.) Biological Treatment of Sewage and Industrial Wastes Volume 1: Aerobic Oxidation. Reinhold Publishing Corporation.

JENKINS D, RICHARD GM and DAIGGER GT (1993) Manual on the Causes and Control of Activated Sludge Bulking and Foaming ( $\left.2^{\text {nd }} e d n.\right)$ Lewis Publishers: USA.

LAPARA TM and ALLEMAN JE (1999) Thermophilic aerobic wastewater treatment. Water Res. 33 (4) 895-908.

PERTTULA M, KONRADSDOTTIR M, PERE J, KRISTJANSSON JK and VIIKARI L (1991) Removal of Acetate from NSSC sulphite pulp-mill condensates using thermophilic bacteria. Water Res. 25 599.

RINTALA J and LEPISTO R (1993) Thermophilic Anaerobic-aerobic and aerobic treatment of kraft bleaching effluents. Water Sci. Technol. 28 (2) 11-16.

ROZICH AF and COLVIN RJ (1997) Design and operational considerations for thermophilic aerobic reactors treating high strength wastes and sludges. Proc. 52 $2^{\text {nd }}$ Industrial Waste Conference. Purdue University. Ann Arbor Press. U.S.A.

RUDOLF W and AMBERG HR (1953) White water treatment V. Aeration with nonflocculant growths. Sewage Industrial Wastes 2570.

STANDARD METHODS (1995) Standard Methods for the Examination of Water and Wastewater (19 ${ }^{\text {th }} \mathrm{edn}$.) American Public Health Association. Washington, DC.

THOMPSON G, SWAIN J, KAY M and FORSTER CF (2001) The treatment of pulp and paper-mill effluent: A review. Biores. Technol. 77 (3) 275-286.

TRIPATHI CS and ALLEN DG (2000) Comparison of mesophilic and thermophilic aerobic biological treatment in sequencing batch reactors treating bleached kraft pulp-mill effluent. Water Res. 33 (3) 836-846.

VOGELAAR JCT, KLAPWIJK A, VAN LIER JB, and RULKENS WH (2000) Temperature effects on the oxygen transfer rate between 20 and $55^{\circ}$ C. Water Res. 34 (30) 1037-1041. 